\title{
HOW CORPORATE GOVERNANCE AND CSR DISCLOSURE AFFECT FIRM PERFORMANCE?
}

\author{
Muhammad Suhaib Manzoor, Ramiz ur Rehman, \\ Muhammad Islam Usman, Muhammad Ishfaq Ahmad
}

\section{Introduction}

CSR (corporate social responsibility) disclosure evolved as a result of corporate reporting in response to changes in conditions in which companies operate. Gray, Owen and Adams (1996) describe CSR disclosure/reporting as "the process of communicating the social and environmental effects of the economic actions of organizations to particular interest groups within society and society at large". Elkington (1997) states that the terms CSR reporting, Social Reporting, Corporate Citizenship, Sustainability Reporting and Triple Bottom Line Reporting have been employed in the studies interchangeably. To meet $21^{\text {st }}$ century corporate challenges, the corporate reporting system has changed somehow with an inclusion of non-financial disclosure. Krasodomska and Cho (2017) explain the extent of non-financial reporting presented by the corporation regarding activities such as human resources, risk management, product innovation and quality, and impact of corporate decisions on environment and society. The inclusion of this information has become a valuable tool for stakeholders to access the present value of companies and to project their growth. Jamali (2008) and Krasodomska and Cho (2017) state that companies are allocating more resources and exerting more efforts to disclose rich information that companies believe to be useful for the stakeholders. One reason for such disclosure is to convey useful information to stakeholders. Additionally, the need to disclose information is also driven by the growing awareness of public related to CSR issues, thus forcing companies to disclose their CSR efforts. Stevie and van Chris (2016) conclude that companies' decisions to report CSR are highly motivated by the factors such as community concerns and shareholder rights.

In this regard, CSR disclosure is highly motivated by the external factor rather than internal factors such as board characteristics and ownership structure. From a strategic point of view, the link between CSR disclosure and firm performance is knotty on the basis of manager's strategic decision to allocate resources to CSR activities (Wu \& Shen, 2013). Unperceiving the effect of internal corporate factors can be detrimental to the stated relationship between CSR and firm performance, as the internal players especially the managers have the most influencing discretionary role than others (Nekhili, Nagati, Chtioui, \& Rebolledo, 2017). In this regard, the disclosed CSR information does not truly depict the relation between CSR and firm performance. Equivocal results in the literature suggest the need for further research to determine the relation between CSR and firm performance and to understand the motives and methods of the firm to get engaged in CSR activities (Margolis \& Walsh, 2003). Further, this relationship has different results for firms engaged in the service industry (Jizi, Salama, Dixon, \& Stratling, 2014) and for firms in the manufacturing industry (Nekhili et al., 2017). Firms in the service industry such as banks do not harm the environment or community by pollution as firms in manufacturing do. However, the lending decision and financial provision seem to affect the stakeholders.

Surprisingly the above motives are paid less attention in developing countries and emerging markets. Ali, Frynas and Mahmood (2017) hold that in developing countries, CSR disclosure is heavily influenced because of international buyers, foreign investors, international media and international regulatory bodies. This potential value of CSR disclosure has led companies to disclose CSR information and urged researchers to consider research on CSR disclosure. However, Krasodomska and Cho (2017) study in polish context suggests that CSR disclosure has less value 
not only for financial analysts but also for respondent surveyed who also place negligible importance to CSR disclosure and the quality of CSR disclosure. Additionally, in contrast to developed economies, CSR studies in emerging economies merely used content analysis approach, and mostly the studies involve the countries Malaysia, China, South Africa and Singapore (Fifka, 2013).

The aim of this study is two-fold. In first instance, the study intends to examine the impact of CSR disclosure on firm performance in the emerging market context such as Pakistan. Few studies are available in the literature regarding developing countries context but the evidences are inconclusive (Naeem \& Welford, 2009; Syed \& Butt, 2017; Javaid Lone, Ali, \& Khan, 2016). Further, it determines the moderating role of executive directors in explaining the relationship between CSR disclosure and firm performance. It would be an interesting finding that how executive directors involve in the decisions of CSR disclosure, which leads to firm performance. The moderating role of executive director in the link between CSR disclosure and firm performance has rarely examined in the CSR literature. Moreover, the moderation role of industry dummy is also examined in the paper to explain the link between CSR disclosure and firm performance. The second objective of this paper is to examine the impact of ownership structure on firm performance in the presence of industry moderation. The ownership structure of firm is determined with the help of managerial, foreign and state ownership. The data of all listed firm at Pakistan Stock exchange from 2012-2016 is included in the study. The study insights will help the firms and strategic decision makers to opt for a strategy where to enhance firm performance while considering the role of CSR disclosure and corporate governance. Not only this study will help a firm to accept and adopt CSR disclosure more regularly as a favourable tool to enhance firm performance where it is motivated and adopted voluntarily but also will encourage corporate governance mechanism under corporate governance laws and rules of Pakistan.

The next section of the paper discusses the wider role of CSR and its practices. It also explains the institutions and legislative role in defining CSR for the firms in Pakistan. Section 2 explains the theoretical framework specific to CSR and firm performance. This section formulates the study hypotheses with the help of literature. Section 3 demonstrates the research design of the study. Section 4 discusses the results of the paper and last section of the paper concludes the overall findings of the paper.

\section{CSR in Pakistan}

In developed countries, CSR constitutes as a key factor for long corporate survival by gaining trust in society, but in Pakistan, CSR is a new occurrence, growing steadily with time (Sajjad \& Eweje, 2014). However, there is a paucity of research on CSR in context to Pakistan, which has emerged as a latent market to global world in past five years. With recent reclassification of Pakistan in $\mathrm{MSCl}$ index covering $85 \%$ of the equity universe of Pakistan equity market, the country has attained a massive milestone in the current decade. KSE 100 index, which represents the equity of 100 top companies out of all companies listed in Pakistan stock exchange, crossed the 50,000 points in 2017. According to KPMG report 2015, CSR reporting in Asian countries have improved significantly since 2013, and now more companies report CSR in Asia than companies in other parts of the world. Naeem and Welford (2009) assert that business in Pakistan is unable to consider the corporate social responsibility. However, the situation has much changed in 2009, after a push from Securities and Exchange Commission of Pakistan (SECP) enabled CSR reporting as essential for companies. Afterward, the approval of CSR disclosure guideline in 2012 was a strengthening move for the encouragement of CSR disclosure in public listed firms of Pakistan. Several other groups and organization such as CSR Association of Pakistan, National Forum for Environment and Health (NFEH), Corporate Social Responsibility Center Pakistan, Sustainable Development Policy Institute, Triple Bottom Line Pakistan, Corporate Social Responsibility Pakistan, MNCs and Responsible Business Initiative Pakistan have exerted their efforts to promote CSR awareness and CSR disclosure culture in organizations of the Pakistan. Sajjad and Eweje (2014) investigate that multinational companies and few big local companies have well-defined CSR policies. These companies have favorable CSR awareness and disclose CSR, resulting in the motivation for other companies to disclose CSR and to engage in CSR activities. 
CSR research in Pakistan initiated early as unidirectional, where researchers and managers focused only on few aspects of CSR at a time. Even the firms, which document the CSR activities, found to be focused more on labor and environment protection areas of CSR (Naeem \& Welford, 2009). Apparently, the keen attention of researchers in Pakistan to limited areas of CSR derived from the issues of replacement of child labor for adult labor in industry pertaining in the early twentieth century (Ray, 2000). Henceforth, the focus of CSR research was confined mostly to the labor, education and health aspects of CSR until the involvement of SECP to foster the CSR practices. Despite this, the context of CSR research in Pakistan is mostly theoretical (Sajjad \& Eweje, 2014) and no profound empirical study has been done to grasp all the aspects of CSR.

\section{Literature Review and Theoretical Framework}

\subsection{CSR and Firm Performance}

CSR disclosure has been widely considered to fortify the firms' performance, albeit this relation is merely checked in emerging markets. Besides this, literature is populated with baffling results, showing no definite and profound relationship of CSR with firm performance. Some studies show a positive association between CSR and firm performance (Agyemang \& Ansong, 2017; Kabir \& Thai, 2017), some shows a negative relation (Jennifer Ho \& Taylor, 2007), while other shows no relationship (Reverte, 2009). These equivocal results are because of an ambit theoretical and empirical drawback in the extent to this relationship. The model of the studies was unspecified because of omission of essential determinants of firm performance. More studies also highlight the extant of this relationship is ill drawn because of corporate stakeholder mismatching (Wood \& Jones, 1995), disregard for contingency elements (Ullmann, 1985), omitted variable bias (Aupperle, Carroll, \& Hatfield, 1985), neglecting mediating factors (Agyemang \& Ansong, 2017) and measurement errors (Waddock \& Graves, 1997).

From stakeholder theory perspective, CSR disclosure allows managers to manage different stakeholders by reducing the likelihood of negative information such as fiscal, regulatory or legislative (Hillman \& Keim, 2001), thus increasing the stakeholder's' confidence in the firm. Furthermore, CSR disclosure enables firms to attain intangible assets such as good will (Hull \& Rothenberg, 2008) and an increased demand for services and product by working in the same manner as advertising works (Sen \& Bhattacharya, 2001). Firms in emerging market believe that slack resources as indispensable to support their CSR activities. Cheng, Lin and Wong (2016) states that firms in emerging markets expect that such an activities will help to improve corporate image and to maximize shareholders wealth. Unlike in western markets, where CSR perceived as a sign of responsible attitude of a firm towards the citizens, CSR in emerging markets is viewed more as a business strategy to maximize the value. Stainer (2006) regards CSR as a strategic tool to achieve firm's objective even when a firm becomes unable to generate sufficient profits and when its sustainability is at risk. Such an incentives of CSR disclosure lead us to infer our first hypothesis.

$\mathrm{H}_{0}^{1}$ : CSR disclosure is negatively associated with firm performance.

$\mathrm{H}_{a}{ }^{1}$ : CSR disclosure is positively associated with firm performance.

\subsection{Moderating Effect of Executive Director and Industry Type on CSR and Firm Performance}

To gauge the extent of corporate governance in detail, further consideration of board structure is pivotal. The role of board structure diffused in the Agency theory in which manager act as a steward for the stakeholders of the firm. Jizi et al. (2014) state the role of boards with a high proportion of independent directors as an effective watchdog for the firm. Independent directors are believed to derive long-term firm value and a high degree of transparency. Further, because of less dependency of independent directors on the CEO than executive directors, they tend to improve firm performance and better control the firm. Zhu, Ye, Tucker and Chan (2016) confirm the argument and find that independent directors have strong and influential decision making in a group and are positively linked with firm value (Reguera-Alvarado \& Bravo, 2017). However, Liu, Wei and Xie (2014) conclude that firms with female executive directors have better firm performance than firms with female independent directors. This argument 
supports that executive effect in firm outweighs the monitoring effect of independent directors. This monitoring role of executive directors also helps to encourage and establish a sound CSR disclosure environment in the firms. Haniffa and Cooke (2005) find Malaysian firms with executive directors report more CSR. In this context, we believe that executive directors have a moderating effect of CSR disclosure and firm performance.

$\mathrm{H}_{0}^{2}$ : Executive board of directors positively moderate the relationship between CSR disclosure and firm performance.

$\mathrm{H}_{a}^{2}$ : Executive board of directors negatively moderate the relationship between CSR disclosure and firm performance.

Further, it is also desirable to assert the moderating effect of industry type on CSR disclosure and firm performance. Different levels of CSR disclosure and firm performance have been observed in different industries. Syed and Butt (2017) find a significant relationship between CSR disclosure and industry type and suggest the role of industry type in CSR disclosure. They conclude that companies in different industries have diverse motives to disclose CSR activities such as more environmental information disclosure by the chemical industry. Bayoud (2012) describes such motives as to enhance the company image and profit. In light of these studies, the following hypothesis has been developed to check the moderating effect of industry type on CSR disclosure and firm performance.

$\mathrm{H}_{0}{ }^{3}$ : Industry type negatively moderates the relationship between CSR disclosure and firm performance.

$\mathrm{H}_{a}{ }^{3}$ : Industry type positively moderates the relationship between CSR disclosure and firm performance.

\subsection{Ownership Structure and Firm Performance}

We further seek whether there is any potential association between ownership structure and firm performance. Most studies promise ownership structure as a key variable of the corporate governance as it supplies the information about the power of decision makers in the corporation. Recent empirical research of Kumar and Zattoni (2014) elaborates that listed companies in non-Anglo-American countries controlled by the larger shareholder, having the highest ultimate decision making power in the corporation, thus enhancing the firm performance by strategic decisions.

Ownership structure has been measured on the basis of a set of variables such as managerial ownership, foreign ownership, and state ownership. These dimensions explain the concentration of power in the corporation and its impact on the performance. Foreign ownership exerts pressure on managers to boost firm performance than any other type of ownership concentration. It is believed that firm with foreign ownership has higher firm performance than other firms. Jeon, Lee and Moffett (2011) demonstrate in their study of Korean economy that foreign investor applies more rigorous standards and practices when they evaluate the management decisions, thus they have more voice in the firm than any other group. Khan, Muttakin and Siddiqui (2013) assert that due to foreign market exposure, foreign investors have different knowledge and values, thus force a company to disclose more social and environmental information for decision making. Studies in Asian markets context yield a significant positive result of foreign ownership with firm performance (Nakano \& Nguyen, 2013). On the basis of the previous studies, we conjecture that our result will match the past literature.

$\mathrm{H}_{0}^{4}$ : Foreign ownership is negatively related to firm performance.

$\mathrm{H}_{a}^{4}$ : Foreign ownership is positively related to firm performance.

One key aspect of ownership concentration that we included in the study is managerial ownership. Most of the research of ownership is stipulated by using the managerial ownership. Based on efficiency perspective, higher managerial concentration leads towards higher managerial monitoring, thus reduce the agency cost (Rashid, 2016). Additionally, managerial ownership helps to reduce agency cost by increasing motivation and incentives for employees and align the interest of employees with that of principal. However, very few studies construct the relationship between managerial ownership and firm performance. Rose (2005) rejects the hypothesis on the grounds of failing to find any significant relation between managerial ownership and firm performance. Moreover, controlling for a set of variables, Mandacı and Gumus (2010) find a negative impact of managerial ownership on firm performance. Jensen and Meckling (1976) 


\section{Business Administration and Management}

explain that higher managerial ownership may lead to agency problem and thus deteriorate the firm performance. Managers become cautious about their interest in the presence of higher managerial ownership hence, firm performance declines.

$\mathrm{H}_{0}{ }^{5}$ : Managerial ownership is positively related to firm performance.

$\mathrm{H}_{a}^{5}$ : Managerial ownership is negatively related to firm performance.

\subsection{Moderating Role of Industry Type in State Owned Ownership and Firm Performance}

Another type of ownership concentration, believes to affect the firm performance is state ownership. Phung and Mishra (2016) find a convex relationship between firm performances and state ownership and mention that state ownership has different motives such as decreasing the unemployment, social concern, and political motive. Furthermore, such goals have a stark deviation from the primary goal of the firm, the shareholder's wealth maximization. A proponent of this approach, Gunasekarage, Hess and Hu (2007) investigate the effect of ownership structure on firm performance and find a negative relationship. However, state ownership is considered to enhance firm performance by helping firms to raise capital easily (Firth, Lin, \& Wong, 2008). Le and Buck (2011) also indicate that connection with state helps the firm to raise capital from different sources by getting favor from government and thereby enhance firm performance. In the case of Pakistan, we found that most of the state investment held in service based companies and such companies are a low performer than other companies included in the sample. Based on this, we infer that state ownership in service based companies has low firm performance.
$\mathrm{H}_{0}^{6}$ : Industry type positively moderates the relationship between state ownership and firm performance.

$H_{a}{ }^{6}$ : Industry type negatively moderates the relationship between state ownership and firm performance.

\section{Research Design \\ 3.1 Sample}

The sample data consists of 96 companies out of KSE-100 index companies, listed in the Pakistan stock exchange from the period 2012 to 2016. The description of the sample selection is presented in Tab 1. Out of 100 top listed companies (KSE-100 Index) in PSX, four companies are ignored because of unavailability of the data over the prescribed period. Further, out of 35 sectors that are part of the KSE-100 index, the data for 34 sectors is collected from 2012 to 2016 . The sample consists of 64 companies those are in product industry, and the remaining 32 belong to the service industry. The sample data has collected for five years by using the information published and disclosed in the annual reports of the companies. Additionally, CSR index is computed by using CSR disclosures, corporate governance disclosures, directors' report, Chairman's statement, and notes to the financial statement contained in annual reports.

\subsection{Model Specification}

On the basis ofhypothesis above, we use panel data regression analysis (fixed or random) to test the significance of the models. We developed four models to capture the immaculate effect of explanatory variables in different models. All the models and tests are evaluated in ' $R$ ' by using the plm package, providing a range of flexibility and accessibility to do panel data analysis.

Tab. 1: Sample description

\begin{tabular}{l|r}
\multicolumn{1}{c|}{ Sample size } & \\
\hline Number of companies & 100 \\
\hline Less: companies wanting incumbent information & 4 \\
\hline Total sample size & 96 \\
\hline
\end{tabular}




$$
\begin{aligned}
& F P E R_{i t}=\alpha_{i t}+C S R D_{i t}+F S I Z E_{i t}+\epsilon_{i t} \\
& \text { FPER }_{i t}=\alpha_{i t}+\text { CSRD }_{i t}+\text { FSIZE }_{i t}+ \\
& +I I N D_{i t}+E X D_{i t}+C E O D_{i t}+E X D_{i t} \times \\
& \times \operatorname{CSRD}_{i t}+\epsilon_{i t} \\
& F P E R_{i t}=\alpha_{i t}+F_{i t} E_{i t}+F R O W N_{i t}+ \\
& +S_{T O W N}+M A N O W N_{i t}+I N D S_{i t}+ \\
& +I N D S_{i t} \times S T O W N_{i t}+\epsilon_{i t} \\
& \text { FPER }_{i t}=\alpha_{i t}+\operatorname{CSRD}_{i t}+\text { FSIZE }_{i t}+ \\
& +I I N D_{i t}+E X D_{i t}+C E O D_{i t}+ \\
& +F^{\prime l} N_{i t}+S_{i l} O W N_{i t}+M A N O W N_{i t}+ \\
& +\operatorname{INDS}_{i t}+\operatorname{INDS}_{i t} * \operatorname{STOWN}_{i t}+ \\
& +\operatorname{CSRD}_{i t} * I N D S_{i t}+\epsilon_{i t}
\end{aligned}
$$

where FPER, Firm Performance calculated by the natural log of firms' market value of equity excluding preferred stock (number of shares * market value of shares). Koo and Maeng (2006) argue that market-based performance measures are a good tool than conventional accounting based measures because of less manipulation by the managers. CSRD, corporate social responsibility disclosure index/score; FSIZE, firm size measured by the natural log of total assets; IIND, proportion of independent directors on board; EXD, proportion of executive directors on board; CEOD, factor (dummy) variable with levels non-dual and dual; FOROWN, percentage of shares hold by the foreign owners; STOWN, percentage of shares owned by the state; MANOWN, percentage of shares hold by the managers; INDS, factor (dummy) variable having levels service and product.

Model 1 beholds the effect of CSR disclosure on firm performance, while controlling for the firm size and tests our first hypothesis $\left(\mathrm{H}_{0}{ }^{1}\right)$ of CSR disclosure is negatively associated with Firm performance. CSRD index/score is calculated by using the data from the annual reports of the firm, developing a modified list of 20 items (see appendix), on the same grounds as developed in the previous studies (Jizi et al., 2014; Khan et al., 2013). Each category of CSRD index/score is rated from a range of 0 to 1 on the basis of the richness of information disclosed in the annual report. Jizi et al. (2014) affirm the use of annual reports as reliable to access the CSR disclosure instead of published CSR reports. Accordingly, the CSRD is calculated on the basis of maximum attained score for a company divided by the maximum total score of 20 .
Further, we check the reliability of the assigned CSRD scores with the use of Cronbach's coefficient alpha from psych package. Consistent with the results of previous studies such as Jizi et al. (2014) (Kripendroff's alpha of 0.80), and Gul and Leung (2004) (Cronbach's coefficient alpha of 0.51), the Cronbach's coefficient alpha for the out study of CSR disclosure index/score is 0.62 . This statistics provides the consistent reliability of alpha in accordance with previous studies. Firm size (FSIZE) is used as a control variable, and its inclusion in all models is consistent with previous studies (Jizi, 2017).

Model 2 tests the moderating role of E.D in explaining link between CSR and firm performance. This model will be used to evaluate $\mathrm{H}_{0}{ }^{2}$. Key explanatory variables included in the model are IIND, EXD and CEOD. IIND represents the proportion of independent directors in the board, will check the monitoring role of independent directors (Nekhili et al., 2017). CEOD is dummy variable which holds 1 if the same person is the CEO and the chairman of the firm, otherwise 0 (Duru, lyengar, \& Zampelli, 2016). The variable EXD* CSRD checks the moderating effect of CSRD on the relationship between executive directors (EXD) and firm performance (FPER).

In model 3, we will regress the ownership concentration variable against the dependent variable. We will consider the impact of foreign ownership (FORWON), state ownership (STOWN) and managerial ownership (MANOWN) on firm performance. Moreover, we will also examine the effect of state ownership on firm performance on the basis of industry dummy variable. For this purpose, the interacted variable STWON*INDS has been added in the model. This model will test the hypothesis $\mathrm{H}_{0}{ }^{4}, \mathrm{H}_{0}{ }^{5}$ and $\mathrm{H}_{0}{ }^{6}$. FOROWN, STOWN and MANOWN are calculated as the percentage of shares held by the foreign companies and individuals, by state and managers (Nekhili et al., 2017). Additionally, in Model 4 checks the collective effect of all explanatory variables on the firm performance and it also examine the hypothesis $\mathrm{H}_{0}{ }^{3}$. Additionally, the effect of CSR disclosure score/index on firm performance on the basis of the industry has been evaluated by using the interacted variable (Chau \& Gray, 2002). 


\section{Results and Discussion}

Tab. 2 entails the descriptive statistics for all the variables included in the study. The average disclosure score is 0.729 with a standard deviation of 0.184 . The ownership concentration is higher for managerial ownership (MANOWN) with an average of $18.1 \%$, lowest for state ownership (STOWN) with a mean of $7.3 \%$ and an average of $13.4 \%$ for foreign ownership (FORWON). The board structure variables exhibit that $92.7 \%$ of the CEOs in the firms' sample data is not the chairman of the board (CEOD), an average of 20.7 of board independence (INDD) and an average 23.2 for executive directors (EXD) of the sample. Further, $66.9 \%$ of the firms in sample belong to product industry (INDS). The dependent variable, firm performance (FPER) has an average of 23.87 and standard deviation of 1.616. All the variables are tested for stationary using the ADF method and are stationary at the unit level.

Further, we supplementary explore the mean values of all variables against the CSR disclosure (CSRD) for firms with CSRD below and above the mean. T test is deployed to test the significance of mean differences between groups of firms with CSRD > mean and CSRD
$<$ mean. The test results in Tab. 3 show the variation among variables in both groups and the results are significant at less than 0.01 and 0.10 levels. Firms in the service industry are less disclosing the CSR and have CSRD < mean. Firms with higher board independence are more disclosing CSR and are significant at a level less than 0.01 . Additionally, firms with a CSR disclosure index/score higher than the mean have state ownership (STOWN) and higher firm performance (FPER). However, managerial ownership (MANOWN) and firms with executive directors (EXD) have disclosure index/score less than the mean. Also, a firm with the non-dual the role of CEO (CEOD) has higher CSR disclosure higher than the mean, but not significant at any level. Firm size (FSIZE), which is a control variable in our study, also differ significantly between both groups and is higher for group CSRD > mean. These results show the variation among variables among the variables and standing of CSRD variable in our study. Fig. 1 shows the means plot of CSRD over the period of five years and reports the increase in CSRD for a sample size of 96 firms in each year.

To account for multicollinearity among the variables, Tab. 4 presents the correlation matrix. Firm performance (FPER) is positively

\section{Tab. 2: Descriptive statistics of explanatory and independent variables}

\begin{tabular}{l|c|c|c}
\multicolumn{1}{c|}{ Variable } & Mean & Median & Std. Dev. \\
\hline CSRD & 0.729 & 0.800 & 0.184 \\
\hline FSIZE & 24.330 & 24.130 & 1.784 \\
\hline FOROWN & 0.134 & 0.038 & 0.227 \\
\hline STOWN & 0.073 & 0.004 & 0.165 \\
\hline MANOWN & 0.181 & 0.015 & 0.562 \\
\hline INDD & 0.207 & 0.143 & 0.145 \\
\hline EXD & 0.232 & 0.222 & 0.135 \\
\hline CEOD & 0.927 & 2.000 & 0.260 \\
\hline INDS & 0.669 & 1.000 & 0.471 \\
\hline FPER & 23.870 & 23.890 & 1.616 \\
\hline
\end{tabular}

Notes: FPER, Firm Performance calculated by natural log of firms' market value (number of shares * market value of shares); CSRD, corporate social responsibility disclosure index/score; FSIZE, firm size measured by the natural log of total assets; IIND, proportion of independent directors on board; EXD, proportion of executive directors on board; CEOD, factor (dummy) variable with levels non-dual* and dual; FOROWN, percentage of shares hold by the foreign owners; STOWN, percentage of shares owned by the state; MANOWN, percentage of shares hold by the managers; INDS, factor (dummy) variable having levels service and product*. 


\begin{tabular}{|c|c|c|c|}
\hline $\begin{array}{l}\text { Differen } \\
\text { and low }\end{array}$ & de of the exp & variables be & s with higher \\
\hline Variables & CSRD > mean & CSRD $<$ mean & p-value \\
\hline FSIZE & 24.650 & 23.720 & $0.000^{* * *}$ \\
\hline FOROWN & 0.125 & 0.149 & 0.261 \\
\hline STOWN & 0.085 & 0.049 & $0.010^{* * *}$ \\
\hline MANOWN & 0.101 & 0.328 & $0.001^{* * *}$ \\
\hline INDD & 0.223 & 0.178 & $0.001^{* * *}$ \\
\hline EXD & 0.210 & 0.273 & $0.000^{* * *}$ \\
\hline CEOD & 0.936 & 0.911 & 0.347 \\
\hline INDS & 0.302 & 0.385 & $0.073^{* *}$ \\
\hline FPER & 24.230 & 23.210 & $0.000^{* * *}$ \\
\hline
\end{tabular}

Source: own calculation

Notes: FPER, Firm Performance calculated by natural log of firms' market value (number of shares * market value of shares); CSRD, corporate social responsibility disclosure index/score; FSIZE, firm size measured by the natural log of total assets; IIND, proportion of independent directors on board; EXD, proportion of executive directors on board; CEOD, factor (dummy) variable with levels non-dual* and dual; FOROWN, percentage of shares hold by the foreign owners; STOWN, percentage of shares owned by the state; MANOWN, percentage of shares hold by the managers; INDS, factor (dummy) variable having levels service ${ }^{*}$ and product. ${ }^{* * *},{ }^{* *}=$ Statistically significant at less than 0.01 and 0.10 level.

\section{Fig. 1: Means plot of CSRD over years}

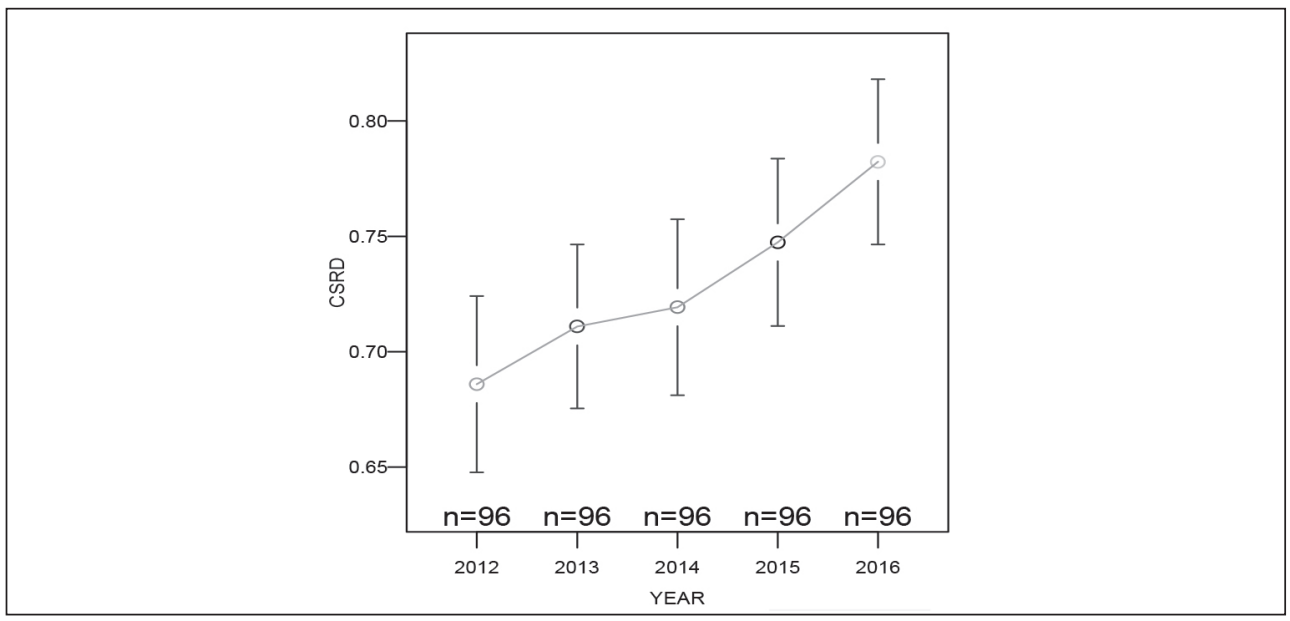

Source: own

related to CSR disclosure index/score (CSRD), with a $p$-value of 0.363 . Managerial ownership (MANOWN) is negatively related to firm performance. However, Firm performance is positively related to state ownership (STOWN) $(p=0.204)$ and foreign ownership (FOROWN) $(p=0.154)$. The correlation between board structure variables and firm performance is positive for independent directors (INDD) $(p=0.202)$ and CEO non-duality (CEOD) $(p=0.082)$, but negative for executive directors (EXD) $(p=0.262)$. Control variable, firm size 


\section{Business Administration and Management}

(FSIZE) is positively related to firm performance $(p=0.602)$. Firm performance is negatively related to industry variable (INDS) $(p=0.036)$.

Tab. 5, reports the results of panel data regression using firm performance as the dependent variable. In model 1, CSR disclosure index/score (CSRD) is regressed against the firm performance with an inclusion of control variable, firm size (FSIZE). The null hypothesis of the Hausman test is not rejected for model 1 and we used the random model to check the impact of explanatory variables on the dependent variable. The result shows that CSR disclosure index/score is positively and significantly related $(p<0.01)$ with firm performance. The model explains $24.1 \%$ variation in the dependent variable due to the inclusion of explanatory variable and control

\section{Tab. 4: Correlation matrix}

\begin{tabular}{l|c|c|c|c|c|c|c|c|c|c} 
& CSRD & FPER & MAWNOWN & STOWN & FOROWN & FSIZE & EXD & INDD & CEOD & INDS \\
\hline CSRD & 1 & & & & & & & & & \\
\hline FPER & 0.363 & 1 & & & & & & & & \\
\hline MAWNOWN & -0.236 & -0.236 & 1 & & & & & & & \\
\hline STOWN & 0.042 & 0.204 & -0.118 & 1 & & & & & & \\
\hline FOROWN & 0.059 & 0.154 & -0.063 & -0.110 & 1 & & & & & \\
\hline FSIZE & 0.215 & 0.602 & -0.188 & 0.400 & -0.033 & 1 & & & & \\
\hline FXD & -0.169 & -0.262 & 0.217 & -0.163 & 0.108 & -0.323 & 1 & & & \\
\hline INDD & 0.077 & 0.202 & -0.019 & 0.142 & -0.006 & 0.301 & -0.163 & 1 & & \\
\hline CEOD & 0.032 & 0.082 & 0.019 & -0.050 & -0.025 & 0.070 & -0.219 & 0.054 & 1 & \\
\hline INDS & -0.058 & -0.036 & -0.059 & 0.157 & -0.066 & 0.389 & -0.337 & 0.018 & 0.129 & 1 \\
\hline
\end{tabular}

Source: own calculations

Notes: FPER, Firm Performance calculated by natural log of firms' market value (number of shares * market value of shares); CSRD, corporate social responsibility disclosure index/score; FSIZE, firm size measured by the natural log of total assets; IIND, proportion of independent directors on board; EXD, proportion of executive directors on board; CEOD, factor (dummy) variable with levels non-dual* and dual; FOROWN, percentage of shares hold by the foreign owners; STOWN, percentage of shares owned by the state; MANOWN, percentage of shares hold by the managers; INDS, factor (dummy) variable having levels service and product*.

variable in the model. The control variable, firm size (FSIZE) is also positively related to firm performance (FPER) and statistically significant at less than 0.01 levels. These results suggest the role of CSR disclosure in enhancing the firm performance and thus we reject the null hypothesis and accept the alternate hypothesis $\left(\mathrm{H}_{\mathrm{a}}{ }^{1}\right)$ that CSR disclosure is positively associated with the firm performance. Firms, which show responsible business practices and are engaged in CSR activities, have higher firm performance (Kabir et al., 2017). Firm in Pakistan disclose CSR activities to show people about their concern about the CSR activities in community, environment and within firm, which eventually help to enhance profit.

The results of model 2 show the effect of board structure along with CSR disclosure index/score variable on the firm performance. The model explains $19.7 \%$ effect of explanatory variables on firm performance, where CSRD and FSIZE are positively and significantly related to firm performance. CEO duality (CEOD) is negatively related to firm performance and is significant at less than 0.01 levels. It implies that CEO duality leads to lower firm performance and thus suggests the call for non-dual board structure as a default choice instead of dual board structure (Tang, 2017). Independent directors (IIND) are related positively and significantly with firm performance; increase in independent directors strengthen the firm performance (Khan et al., 2013).

Further this model tests the moderating effect of Executive directors (EXD) on the relationship between the CSR disclosure and 
firm performance. Executive directors (EXD) are found to be insignificant, but the interacted variable EXD*CSRD is negatively related to firm performance and is significant at $(p<0.05)$ thus we reject the null hypothesis that Executive directors positively moderates the relationship between CSR disclosure and frim performance. These findings suggest that executive directors alone have not any noticeable effect on firm performance but have a negative a significant impact on firm performance when executive directors (EXD) are engaged in CSR activities. The results support the neoclassical argument that firms face additional cost when they engage in socially responsible activities and hence result in competitive disadvantage (Aupperle et al., 1985).
Model 3 highlights the effect of ownership structure on firm performance. Foreign ownership (FORWON) is positively $(\beta=1.206$ ) related to firm performance and managerial ownership (MANOWN) is negatively $(\beta=-0.489)$ related to firm performance and are statistically significant $(p<0.01)$. The result supports our alternate hypotheses that foreign ownership is positively related to firm performance and managerial ownership is negatively related to firm performance. Despite having low shares, foreign ownership helps to monitor corporate activities and thus improve firm performance (Mukhopadhyay \& Chakraborty, 2017). From results, we corroborate that foreign ownership in Pakistani firm exerts pressure on the management to

\section{Tab. 5: Panel data analysis using firm performance (FPER) as dependent variable}

\begin{tabular}{l|c|c|c|c} 
& $\begin{array}{c}\text { Model 1 } \\
\text { Model = Random } \\
\text { Coefficient }\end{array}$ & $\begin{array}{c}\text { Model 2 } \\
\text { Model = Random } \\
\text { Coefficient }\end{array}$ & $\begin{array}{c}\text { Model 3 } \\
\text { Model = Random } \\
\text { Coefficient }\end{array}$ & $\begin{array}{c}\text { Model 4 } \\
\text { Model = Fixed } \\
\text { Coefficient }\end{array}$ \\
\hline CSRD & $1.807^{* * *}$ & $1.873^{* *}$ & & $0.492^{*}$ \\
\hline FSIZE & $0.529^{* * *}$ & $0.595^{* * *}$ & $0.616^{* *}$ & $0.472^{* * *}$ \\
\hline IIND & & 0.828 & & $1.123^{* *}$ \\
\hline EXD & 1.516 & & -0.253 \\
\hline CEOD & $-1.130^{* * *}$ & & $-1.218^{* * *}$ \\
\hline EXD*CSRD & & -3.359 & & $1.374^{* *}$ \\
\hline FOROWN & & & $1.206^{* * *}$ & 0.522 \\
\hline STOWN & & & 0.301 & $-0.527^{* * *}$ \\
\hline MANOWN & & & $-0.489^{* * *}$ & $-2.462^{*}$ \\
\hline INDS-SER & & & $-1.011^{* * *}$ & 1.401 \\
\hline STOWN*INDS & & 0.244 & 0.0049 \\
\hline CSRD*INDS & & 0.103 & 0.565 & 0.345 \\
\hline $\begin{array}{l}\text { Hausman test } \\
\text { (P Value) }\end{array}$ & 0.508 & 0.251 & 0.316 & 0.268 \\
\hline$R^{2}$ & 0.243 & 0.197 & 0.312 & 19.710 \\
\hline Adjusted R & 0.241 & & 36.556 & \\
\hline F-stat & 76.744 & & & \\
\hline
\end{tabular}

Source: own calculations

Notes: FPER, Firm Performance calculated by natural log of firms' market value (number of shares * market value of shares); CSRD, corporate social responsibility disclosure index/score; FSIZE, firm size measured by the natural log of total assets; IIND, proportion of independent directors on board; EXD, proportion of executive directors on board; CEOD, factor (dummy) variable with levels non-dual and dual; EXD*CSR, interaction of EXD and CSRD; FOROWN, percentage of shares hold by the foreign owners; STOWN, percentage of shares owned by the state; MANOWN, percentage of shares hold by the managers; STOWN* INDS ,interaction of STOWN and INDS; INDS, factor (dummy) variable having levels service and product*; CSRD* INDS, interaction of CSRD and INDS. ${ }^{* * *},{ }^{* *},{ }^{*}$, , = Statistically significant at less than $0.001,0.01$ and 0.05 levels. 
enhance performance as foreign investors have different and shaped knowledge and values. Moreover, local investors also gain confidence to invest in the company when the foreigners in the form of foreign ownership regard a firm. These results support the supposition of the studies in emerging market context (Khan et al., 2013; Nakano \& Nguyen, 2013). However, Managerial ownership result suggests that firm in emerging markets face agency problems that dilutes the firm performance.

We did not find any significant direct effect of state ownership (STOWN) on firm performance. However, we find that state ownership in service industry is negatively related to firm performance and is significant $(p<0.05)$. This supports our alternate hypothesis that industry type negatively moderates the relationship between state ownership and firm performance. The finding suggests that state investment in the service industry is not beneficial for the company itself, providing support to the argument that state goal of investment in the firm and the firm goals do not match correspondingly. State ownership deteriorates firm performance and results in the political intervention (Borisova, Brockman, Salas, \& Zagorchev, 2012). Additionally, the industry dummy variable (INDS) has a negative and a significant effect on firm performance, showing that firms in product industry have better performance than firms in the service industry. These results suggest that state ownership in firms in Pakistan deters firm performance due to corruption, political interference and political condition in the country that are the potential problems of the country.

In model 4, we regressed all the key variables of the study against the dependent variable firm performance (FPER). The Hausman test avows that fixed effect model is the appropriate method to run the model $(p<0.0049)$. Results in this model are in accordance with the results of previous models, and we did not find any prominent variation in the result of each variable concerning model 1, 2 and 3 . Additionally, in this model we will test our hypothesis that industry type negatively moderates the relationship between CSR disclosure and firm performance. The result shows that CSR disclosure in firms, those are engaged in the service industry is positively related to firm performance, thus we reject our null hypothesis. R square value explains $26.8 \%$ variation in the model due to the inclusion of all the stated explanatory variables. The finding suggests different motives of CSR disclosure in different industry types. In Pakistan, most of the state investment is in the service industry, which is more engaged in CSR disclosure as a result of government support to disclose CSR voluntarily.

\section{Conclusions}

In this study, we empirically examine the effect of board characteristics, ownership structure, and CSR disclosure on firm performance. The CSR disclosure by listed firms in developing countries has become a phenomenon during recent times. However, the type of CSR disclosure is still non-financial. However, it is an interesting topic for researchers to evaluate the performance of the firm in the presence of non-financial disclosure of CSR. This study contributes to the existing body of knowledge in developing countries context that how CSR nonfinancial disclosure, especially in the service firms, affect the firm financial performance.

The results of this study reveal that the listed firms in the service sector of developing country disclose less CSR as compared to other sectors. However, CSR disclosure itself has a positive and significant impact on the firm value. It is an interesting finding and in line with CSR literature that CSR has a positive impact on firm financial performance. The positive link between CSR and CFP is mostly verified in developed countries where the awareness about CSR is better than developing countries. The structural and institutional development of CSR is also in its early phases in emerging economies Therefore, the results are very encouraging for developing countries context where the emergence of CSR is a recent phenomenon. Moreover the involvement of executive directors in CSR disclosure has rarely examined in the literature. The study contributes to the CSR literature both empirically and theoretical that how executive director moderates the link between CSR disclosure and firm performance. According to agency theory, the role of executive director in firm's operation may create conflict of interest between managers and shareholders. The CSR based activities may become a potential source of conflict between agents and principal. The manager of a firm takes CSR initiatives to get their social and political benefits at the 
cost of shareholder's wealth. The same has been reflected in the empirical results of this study. The link between CSR disclosure and financial performance of the firm is positive and significant, however, when executive director involves in CSR disclosure then it negatively moderates the relationship between CSR disclosure and firm performance. Further, this study also confirms that the state ownership is more influential in the service firms as compared to other listed firms. Additionally, the state ownership has a negative impact on the service sector firm performance.

\section{References}

Agyemang, O. S., \& Ansong, A. (2017). Corporate social responsibility and firm performance of Ghanaian SMEs: Mediating role of access to capital and firm reputation. Journal of Global Responsibility, 8(1), 47-62. https://doi. org/10.1108/jgr-03-2016-0007.

Ali, W., Frynas, J. G., \& Mahmood, Z. (2017). Determinants of corporate social responsibility (CSR) disclosure in developed and developing countries: a literature review. Corporate Social Responsibility and Environmental Management, 24(4), 273-294. https://doi.org/10.1002/csr.1410.

Aupperle, K. E., Carroll, A. B., \& Hatfield, J. D. (1985). An empirical examination of the relationship between corporate social responsibility and profitability. Academy of Management Journal, 28(2), 446-463. https://doi.org/10.2307/256210.

Borisova, G., Brockman, P., Salas, J. M., \& Zagorchev, A. (2012). Government ownership and corporate governance: Evidence from the EU. Journal of Banking \& Finance, 36(11), 2917-2934. https://doi.org/10.1016/j. jbankfin.2012.01.008.

Chau, G. K., \& Gray, S. J. (2002). Ownership structure and corporate voluntary disclosure in Hong Kong and Singapore. The International Journal of Accounting, 37(2), 247-265. https://doi.org/10.1016/s0020-7063(02)00153-x.

Cheng, S., Lin, K. Z., \& Wong, W. (2016). Corporate social responsibility reporting and firm performance: evidence from China. Journal of Management \& Governance, 20(3), 503-523. https://doi.org/10.1007/s10997-015-9309-1.

Duru, A., lyengar, R. J., \& Zampelli, E. M. (2016). The dynamic relationship between CEO duality and firm performance: The moderating role of board independence. Journal of Business Research, 69(10), 4269-4277. https://doi.org/10.1016/j.jbusres.2016.04.001.

Elkington, J. (1997). Cannibals with forks. In The triple bottom line of 21st century (p. 73).

Fifka, M. S. (2013). Corporate responsibility reporting and its determinants in comparative perspective - a review of the empirical literature and a meta-analysis. Business Strategy and the Environment, 22(1), 1-35. https://doi. org/10.1002/bse.729.

Firth, M., Lin, C., \& Wong, S. M. (2008). Leverage and investment under a state-owned bank lending environment: Evidence from China. Journal of Corporate Finance, 14(5), 642-653. https://doi.org/10.1016/j.jcorpfin.2008.08.002.

Gray, R., Owen, D., \& Adams, C. (1996). Accounting \& accountability: changes and challenges in corporate social and environmental reporting. Upper Saddle River, NJ: Prentice Hall.

Gul, F. A., \& Leung, S. (2004). Board leadership, outside directors' expertise and voluntary corporate disclosures. Journal of Accounting and Public Policy, 23(5), 351-379. https://doi.org/10.1016/j.jaccpubpol.2004.07.001.

Gunasekarage, A., Hess, K., \& Hu, A. J. (2007). The influence of the degree of state ownership and the ownership concentration on the performance of listed Chinese companies. Research in International Business and Finance, 21(3), 379-395. https://doi. org/10.1016/j.ribaf.2007.02.002.

Haniffa, R. M., \& Cooke, T. E. (2005). The impact of culture and governance on corporate social reporting. Journal of Accounting and Public Policy, 24(5), 391-430. https://doi. org/10.1016/j.jaccpubpol.2005.06.001.

Hillman, A. J., \& Keim, G. D. (2001). Shareholder value, stakeholder management, and socialissues:What'sthebottomline? Strategic Management Journal, 22(2), 125-139. https://doi. org/10.1002/1097-0266(200101)22:2<125::AIDSMJ150>3.0.CO;2-H.

Hull, C. E., \& Rothenberg, S. (2008). Firm performance: The interactions of corporate social performance with innovation and industry differentiation. Strategic Management Journal, 29(7), 781-789. https://doi.org/10.1002/smj.675.

Jamali, D. (2008). A stakeholder approach to corporate social responsibility: A fresh perspective into theory and practice. Journal of Business Ethics, 82(1), 213-231. https://doi. org/10.1007/s10551-007-9572-4. 
Javaid Lone, E., Ali, A., \& Khan, I. (2016). Corporate governance and corporate social responsibility disclosure: evidence from Pakistan. Corporate Governance: The International Journal of Business in Society, 16(5), 785-797. https://doi.org/10.1108/cg-05-2016-0100.

Jennifer Ho, L. C., \& Taylor, M. E. (2007). An empirical analysis of triple bottom-line reporting and its determinants: evidence from the United States and Japan. Journal of International Financial Management \& Accounting, 18(2), 123-150. https://doi.org/10.1111/j.1467-646x.2007.01010.x.

Jensen, M. C., \& Meckling, W. H. (1976). Theory of the firm: Managerial behavior, agency costs and ownership structure. Journal of Financial Economics, 3(4), 305-360. https://doi.org/10.1016/0304-405x(76)90026-x.

Jeon, J. Q., Lee, C., \& Moffett, C. M. (2011). Effects of foreign ownership on payout policy: Evidence from the Korean market. Journal of Financial Markets, 14(2), 344-375. https://doi.org/10.1016/j.finmar.2010.08.001.

Jizi, M. (2017). The influence of board composition on sustainable development disclosure. Business Strategy and the Environment, 26(5), 640-655. https://doi.org/10.1002/bse.1943.

Jizi, M. I., Salama, A., Dixon, R., \& Stratling, R. (2014). Corporate governance and corporate social responsibility disclosure: Evidence from the US banking sector. Journal of Business Ethics, 125(4), 601-615. https://doi. org/10.1007/s10551-013-1929-2.

Kabir, R., \& Thai, H. M. (2017). Does corporate governance shape the relationship between corporate social responsibility and financial performance? Pacific Accounting Review, 29(2), 227-258. https://doi.org/10.1108/ par-10-2016-0091.

Khan, A., Muttakin, M. B., \& Siddiqui, J. (2013). Corporate governance and corporate social responsibility disclosures: Evidence from an emerging economy. Journal of Business Ethics, 114(2), 207-223. https://doi.org/10.1007/ s10551-012-1336-0.

Koo, J., \& Maeng, K. (2006). Foreign ownership and investment: Evidence from Korea. Applied Economics, 38(20), 2405-2414. https://doi.org/10.1080/00036840500427817.

Krasodomska, J., \& Cho, C. H. (2017). Corporate social responsibility disclosure: perspectives from sell-side and buy-side financial analysts. Sustainability Accounting, Management and Policy Journal, 8(1), 2-19. https://doi.org/10.1108/sampj-02-2016-0006.
Kumar, P., \& Zattoni, A. (2014). Ownership, managerial entrenchment, and corporate performance. Corporate Governance: An International Review, 22(1), 1-3. https://doi. org/10.1111/corg.12053.

Le, T. V., \& Buck, T. (2011). State ownership and listed firm performance: a universally negative governance relationship? Journal of Management \& Governance, 15(2), 227-248. https://doi.org/10.1007/s10997-009-9098-5.

Liu, Y., Wei, Z., \& Xie, F. (2014). Do women directors improve firm performance in China? Journal of Corporate Finance, 28, 169-184. https://doi.org/10.1016/j.jcorpfin.2013.11.016.

Mandacı, P., \& Gumus, G. (2010). Ownership concentration, managerial ownership and firm performance: Evidence from Turkey. South East European Journal of Economics and Business, 5(1), 57-66. https://doi.org/10.2478/v10033-010-0005-4.

Margolis, J. D., \& Walsh, J. P. (2003). Misery loves companies: Rethinking social initiatives by business. Administrative Science Quarterly, 48(2), 268-305. https://doi.org/10.2307/3556659.

Mukhopadhyay, J., \& Chakraborty, I. (2017). Foreign institutional investment, business groups and firm performance: Evidence from India. Research in International Business and Finance, 39, 454-465. https://doi.org/10.1016/j. ribaf.2016.09.015.

Naeem, M. A., \& Welford, R. (2009). A comparative study of corporate social responsibility in Bangladesh and Pakistan. Corporate Social Responsibility and Environmental Management, 16(2), 108-122. https://doi.org/10.1002/csr.185.

Nakano, M., \& Nguyen, P. (2013). Foreign ownership and firm performance: evidence from Japan's electronics industry. Applied Financial Economics, 23(1), 41-50. https://doi.org/10. 1080/09603107.2012.705425.

Nekhili, M., Nagati, H., Chtioui, T., \& Rebolledo, C. (2017). Corporatesocial responsibility disclosure and market value: Family versus nonfamily firms. Journal of Business Research, 77, 41-52. https://doi.org/10.1016/j.jbusres.2017.04.001.

Phung, D. N., \& Mishra, A. V. (2016). Ownership Structure and Firm Performance: Evidence from Vietnamese Listed Firms. Australian Economic Papers, 55(1), 63-98. https://doi.org/10.1111/1467-8454.12056.

Rashid, A. (2016). Managerial ownership and agency cost: evidence from Bangladesh. Journal of Business Ethics, 137(3), 609-621. 
https://doi.org/10.1007/s10551-015-2570-z.

Ray, R. (2000). Child labor, child schooling, and their interaction with adult labor: Empirical evidence for Peru and Pakistan. The World Bank Economic Review, 14(2), 347-367. https://doi.org/10.1093/wber/14.2.347.

Reguera-Alvarado, N., \& Bravo, F. (2017). The effect of independent directors' characteristics on firm performance: tenure and multiple directorships. Research in International Business and Finance, 41, 590-599. https://doi. org/10.1016/j.ribaf.2017.04.045.

Reverte, C. (2009). Determinants of corporate social responsibility disclosure ratings by Spanish listed firms. Journal of Business Ethics, 88(2), 351-366. https://doi.org/10.1007/ s10551-008-9968-9.

Rose, C. (2005). Managerial Ownership and Firm Performance in Listed Danish Firms: In Search of the Missing Link. European Management Journal, 23(5), 542-553. https:// doi.org/10.1016/j.emj.2005.09.009.

Sajjad, A., \& Eweje, G. (2014). Corporate social responsibility in Pakistan: current trends and future directions. In Corporate Social Responsibility and Sustainability: Emerging Trends in Developing Economies (pp. 163-187). Emerald Group Publishing Limited. https://doi. org/10.1108/s2043-9059_2014_0000008010.

Sen, S., \& Bhattacharya, C. B. (2001). Does doing good always lead to doing better? Consumer reactions to corporate social responsibility. Journal of Marketing Research, 38(2), 225-243. https://doi.org/10.1509/jmkr.38.2.225.18838.

Stainer, L. (2006). Performance management and corporate social responsibility: the strategic connection. Strategic Change, 15(5), 253-264. https://doi.org/10.1002/jsc.761.

Stevie, D., \& Chris van, S. (2016). Motivations for corporate social and environmental reporting: New Zealand evidence. Sustainability Accounting, Management and Policy Journal, 7(3), 449-472. https://doi.org/10.1108/ SAMPJ-08-2015-0070.

Syed, M. A., \& Butt, S. A. (2017). Financial and non-financial determinants of corporate social responsibility: empirical evidence from Pakistan. Social Responsibility Journal, 13(4), 780-797. https://doi.org/10.1108/srj-08-2016-0146.

Tang, J. (2017). CEO duality and firm performance: The moderating roles of other executives and blockholding outside directors. European Management Journal, 35(3), 362-372. https://doi.org/10.1016/j.emj.2016.05.003.
Ullmann, A. A. (1985). Data in search of a theory: Acritical examination of the relationships among social performance, social disclosure, and economic performance of US firms. Academy of Management Review, 10(3), 540-557. https://doi.org/10.5465/amr.1985.4278989.

Waddock, S. A., \& Graves, S. B. (1997). The corporate social performance-financial performance link. Strategic Management Journal, 18(4), 303-319. https://doi.org/10.1002/ (SICI)1097-0266(199704)18:4<303::AIDSMJ869>3.0.CO;2-G.

Wood, D. J., \& Jones, R. E. (1995). Stakeholder mismatching: A theoretical problem in empirical research on corporate social performance. The International Journal of Organizational Analysis, 3(3), 229-267. https://doi.org/10.1108/eb028831.

Wu, M.-W., \& Shen, C.-H. (2013). Corporate social responsibility in the banking industry: Motives and financial performance. Journal of Banking \& Finance, 37(9), 3529-3547. https://doi.org/10.1016/j.jbankfin.2013.04.023.

Zhu, J., Ye, K., Tucker, J. W., \& Chan, K. J. C. (2016). Board hierarchy, independent directors, and firm value: Evidence from China. Journal of Corporate Finance, 41, 262-279. https://doi.org/10.1016/j.jcorpfin.2016.09.009.

Lect. Muhammad Suhaib Manzoor The University of Lahore Faculty of Management Sciences Lahore Business School Pakistan

Suhaib.wahala@gmail.com

Assoc. Prof. Ramiz ur Rehman, Ph.D. The University of Lahore Faculty of Management Sciences Lahore Business School Pakistan Ramiz_rehman@hotmail.com

Assist. Prof. Muhammad Islam Usman The University of Lahore Faculty of Management Sciences Lahore Business School Pakistan

Assist. Prof. Muhammad Ishfaq Ahmad, Ph.D. The University of Lahore Faculty of Management Sciences Lahore Business School Pakistan m_ishfaq452@yahoo.com 


\section{Business Administration and Management}

\section{Appendix A: Results of cluster analysis - selected models}

\begin{tabular}{|c|c|c|}
\hline \multirow{3}{*}{\multicolumn{2}{|c|}{ 1) Community Involvement }} & 1. Charitable Donations \\
\hline & & 2. Sponsorship \\
\hline & & 3. Health and Education \\
\hline 2) & Environmental & 1. Environment Policies \\
\hline \multirow[t]{9}{*}{ 3) } & \multirow[t]{9}{*}{ Employee Information } & 1. Number of Employees \\
\hline & & 2. Employees' Relations \\
\hline & & 3. Employees' Welfare \\
\hline & & 4. Employees' Education \\
\hline & & 5. Employees' Training \& Development \\
\hline & & 6. Employees' Profit-Sharing \\
\hline & & 7. Managerial Remuneration \\
\hline & & 8. Workers' Health and Safety \\
\hline & & 9. Child Labor and Related Actions \\
\hline \multirow[t]{6}{*}{ 4) } & \multirow[t]{6}{*}{ Product and Service Information } & 1. Types of Products Disclosed \\
\hline & & 2. Product Development and Research \\
\hline & & 3. Product Quality and Safety \\
\hline & & 4. Discussion of Marketing Network \\
\hline & & 5. Focus on Customer service \& Satisfaction \\
\hline & & 6. Customer Award/Rating Received \\
\hline 5) & Value-Added Information & 1. Value-Added Statement \\
\hline
\end{tabular}




\section{Abstract}

\section{HOW CORPORATE GOVERNANCE AND CSR DISCLOSURE AFFECT FIRM PERFORMANCE?}

\section{Muhammad Suhaib Manzoor, Ramiz ur Rehman, Muhammad Islam Usman, Muhammad Ishfaq Ahmad}

The study aims to provide empirical evidence of firm performance relation with board characteristics (Independent directors, Executive directors, and CEO duality), ownership structure (Managerial, State, and Foreign ownership) and CSR disclosure. The CSR disclosure by listed firms in developing countries has become a phenomenon during recent times. However, the type of CSR disclosure is still non-financial. However, it is an interesting topic for researchers to evaluate the performance of the firm in the presence of non-financial disclosure of CSR. Firm level panel data has collected for firms listed in KSE-100 index in Pakistan between 2012 and 2016. The study uses panel data analysis to estimate the models using firm size as a control variable. Results of the empirical research indicate that firms in the service industry are less disclosing the CSR, but such disclosure is positively related to firm performance. The authors find evidence that executive directors when engaging into CSR disclosure activities, it negatively and significantly impact the firm performance. The authors qualify the results regarding the CEO duality, independent directors, managerial ownership, state ownership and foreign ownership with impact on firm performance. Further, the results suggest that state ownership is influential in the service industry and negatively affect the firm performance. This study contributes to the existing body of knowledge in developing countries context that how CSR non-financial disclosure, especially in the service firms, affect the firm financial performance. Future research should use cross-country analysis for assessing the models and examining the results across countries, industry, and sectors. From a practical perspective, the results may guide firms how to engage in CSR disclosure activities without hampering the firm performance while considering the other firm level factors. This study is extensively novel in all of its contents and contributes mainly to the literature of CSR disclosure and firm performance.

Key Words: CSR disclosure, service industry, firm performance, corporate governance.

JEL Classification: G34, M14, L25, O14.

DOI: 10.15240/tul/001/2019-3-002 